\title{
CINEMA E TELEJORNALISMO NO DOCUMENTÁRIO TELEVISIVO BRASILEIRO
}

Ivanise Hilbig de Andrade 


\title{
CINEMA E TELEJORNALISMO NO DOCUMENTÁRIO TELEVISIVO BRASILEIRO
}

Resumo: O presente trabalho apoia-se no conceito de gênero televisivo para o estudo do subgênero documentário televisivo brasileiro, identificando o que o constitui enquanto subgênero, bem como apontando alguns dos elementos que são dominantes, residuais e emergentes. Foram analisadas críticas, notícias, reportagens e artigos de opinião veiculados pela imprensa brasileira sobre os programas televisivos Globo Repóter (Globo), SBT Repórter (SBT) e Câmera Record (Record), além de edições dos referidos programas.

Palavras chave:Estudos Culturais; Gêneros Televisivos; Documentário Televisivo

\section{CINE Y TELEPERIODISMO EN DOCUMENTAL TELEVISIVO BRASILEÑO}

Resumen: Este trabajo se basa en el concepto de género televisivo para el estudio del subgénero documental de la televisión brasileña, identificando de lo que constituye como subgénero, así como señalar algunos de los elementos que son dominantes, residuales y emergentes. Se analizó la crítica, noticias, reportajes y artículos de opinión en la prensa brasileña acerca de los programas de televisión: Globo Repórter (Globo), SBT Repórter (SBT) y Câmera Record (Record), y las ediciones de estos programas.

Palabras clave: Estudios Culturales; Géneros televisivos; Documental Televisión

\section{CINEMA AND TV JOURNALISM IN THE BRASILIAN TELEVISION DOCUMENTARY}

\begin{abstract}
This paper is based on the concept of television genre for the study of Brazilian television documentary subgenre, identifying what constitutes while subgenre, as well pointing out some of the elements that are dominant, residual and emergent. It were analyzed criticism, news, features and opinion articles conveyed by the Brazilian press about the television programs: Globo Repórter (Globo), SBT Repórter (SBT) and Câmera Record (Record), besides editions of these programs.
\end{abstract}

Keywords: Cultural Studies; Television genres; Television Documentary 


\section{INTRODUÇÃO}

A cultura está em constante transformação e adaptação e esse movimento reflete-se nas práticas sociais e nos bens culturais, reconfigurando também os modos de produção e recepção (reconhecimento) dos produtos dos meios de comunicação, entre eles a televisão. E acompanhando essas transformações e adaptações da própria sociedade, em termos culturais, sociais, políticos, as emissoras de televisão trabalhampara atender as expectativas de informação e diversão do público, ao mesmo tempo em que atende aos anseios dos patrocinadores e anunciantes, bem como do próprio Poder Público.

Os gêneros televisivos, neste cenário, estão em permanente processo de reconfiguração, seguindo as transformações da cultura e da sociedade, fazendo emergir novas tecnologias, hábitos e formas de produção e consumo. Douglas Kellner (2001, p. 11), descreve cultura como uma"forma de atividade que implica alto grau de participação, na qual as pessoas criam sociedades e identidades. A cultura modela os indivíduos, evidenciando e cultivando suas potencialidades e capacidades de fala, ação e criatividade". E meios de comunicação como a televisão fazem parte desse processo de construção, transformação, adaptação e acumulação de cultura, na medida em que, por um lado, dita comportamentos e crenças, e por outro, torna-se instrumento de construção de identidades e reconhecimento entre os indivíduos de uma sociedade. Para o autor, os textos da cultura damídia não são intrinsecamente coisa alguma, mas incorporam "váriosdiscursos, posições ideológicas, estratégias narrativas, construção de imagense efeitos (por exemplo, cinematográficos, televisivos, musicais) que raramentese integram numa posição ideológica pura e coerente" (KELLNER, 2001, p. 123).

No entanto, de acordo com Gomes (2011), os trabalhos de análise dos programas jornalísticos televisivos ainda carecem de uma metodologia válida e abrangente, quepermita consolidar análise e interpretação. A autora propõe uma análise a partir da perspectiva teórico-metodológica dos Estudos Culturais, em que o telejornalismo é considerado uma forma cultural e uma instituição social, nos termos de Raymond Williams, e são articulados conceitos de estrutura de sentimento, gênero televisivo e modos de endereçamento, para o tratamento de materiais empíricos.

O presente trabalho alia-se, então, à perspectiva da análise cultural de programas jornalísticos televisivos, utilizando o conceito de gênero televisivo para a análise do subgênero documentário televisivo brasileiro. O objetivo é iden- 
tificar as marcas e elementos que o constituem, bem como apontar quaissão dominantes, residuais e emergentes dentro do subgênero.

Nesta análise, o documentário televisivo é entendido como construção social e um subgênero do telejornalismo, na medida em que articula rotinas produtivas e premissas da grande reportagem jornalística no seu trato da informação (conteúdo) e a linguagem estética (forma) do cinedocumentário, tendo sua circulação no meio de comunicação televisão. E por cultura, entende-se o conceito proposto pelosCulturalStudies, que a considera como um espaço de tensionamentos, de disputa, pressões e limites que circunscreve as práticas humanas e institucionais, entre elas a da produção jornalística e, consequentemente, também a produção do subgênero documentário televisivo. Sendo assim:

entendemos que a análise da problemática cultural deve levar em conta o movimento mais amplo da sociedade, e, ao mesmo tempo, perceber a cultura como um espaço de luta e de distinção social (ORTIZ, 1994, p. 147).

Partimos do pressuposto de que as práticas culturais interferem e são constitutivas dos gêneros televisivos, por isso a opção por uma análise do gênero, pois ele permite pensar as relações sociais e históricas nas formas que o documentário televisivo assume ao longo do tempo e nas sociedades em que estas formas são praticadas e instituídas. Assim, o problema de pesquisa que norteia este trabalho é: quais elementos e marcas do subgênero documentário televisivo tornaram-se dominantes, desapareceram e são emergentes, podendo vir a ser tendência nos programas de telejornalismo documental?

Para o trabalho, foram analisadas críticas, notícias, reportagens e artigos de opinião veiculados pela imprensa brasileira sobre os programas televisivos Globo Repórter (Globo), SBT Repórter (SBT) e Câmera Record (Record), além de exemplos de algumas edições dos referidos programas, selecionadas aleatoriamente $^{1}$.A escolha pela análise do conteúdo produzido pela imprensa sobre os programas justifica-se pelo entendimento, neste artigo, de que uma análise

1 A seleção foi feita a partir de buscas nos sites das próprias emissoras, no Memória Globo (www.memoriaglobo.globo.com) e Youtube (www.youtube.com), usando como recurso de busca o nome dos programas.Apesar de aleatória, ou seja, sem uma preocupação com um período específico, houve um esforço por assistir as primeiras edições dos programas, quando disponíveis na internet, e algumas edições veiculadas nas décadas de 1980, 1990, 2000 e no ano de 2012. 
cultural considera o sujeito (receptor) e seu processo ativo na produção de sentido na cultura, na medida em que é esse sujeito que reconhece e reconfigura constantemente os gêneros televisivos. A partir dos artigos de opinião, reportagens e críticas é possível identificar elementos que revelam como a audiência, ou seja, como os receptores, reconhecem as regularidades do gênero e como isso impacta nas decisões acerca de formatos e linguagens.

\section{GÊNEROS TELEVISIVOS E O DOCUMENTÁRIO}

De acordo com Raymond Williams (2005, p. 22), a televisão é, ao mesmo tempo, uma tecnologia e uma forma cultural, e o jornalismo, uma instituição social, como família, escola, igreja, colaborando para a configuração do modo de vida das pessoas, na medida em que impõe significados, valores e atividades. O telejornalismo é, então, conforme Gomes (2011, p. 19), uma construção social, pois se configura numa formação econômica, social, cultural particular e cumpre funções fundamentais nessa formação. Sendo assim, a função social de tornar a informação publicamente disponível conferida ao jornalismo é da ordem da cultura e desenvolveu-se dessa forma a partir das práticas sociais e culturais das sociedades.

Raymond Williams (1979), ao tratar do campo literário, reflete sobre a concepção de gênero, defendendo uma perspectiva histórica e cultural para o conceito. Segundo o autor, os gêneros literáriossão convenções, normas historicamente construídas, que servem para agrupar, reunir e organizar uma diversidade de representações e significados. Ao aceitar o caráter histórico e mutável dos gêneros, Williams afirma a impossibilidade ou a ineficácia de reduzir todas as obras literárias reais possíveis a categorias estanques.

O autor considera o gênero como uma forma cultural que diz sobre o que é historicamente e culturalmente construído e socialmente compartilhado como próprio do gênero em questão. A noção de gênero, portanto, é pensada numa relação estreita entre as obras e as sociedades e os períodos nos quais foram originadas ou praticadas, mas que existe para além dessas sociedades e períodos. A partir das concepções de Raymond Williams e outros autores filiados aosEstudos Culturais, Itania Gomes constrói uma definição de gênero televisivo. Para a autora:

O conceito de gênero televisivo permite compreender as regularidades e as especificidades em produtos que se configuram histo- 
ricamente - ele permite dizer tanto do jornalismo como ideologia, valores, normas quanto das formas culturais historicamente dadas e, sobretudo, vincular nosso objeto de análise ao processo comunicacional - gênero televisivo é uma estratégia de comunicabilidade (GOMES, 2011, p. 18).

Por esse viés, é possível afirmar que as regularidades permitem o reconhecimento de marcasdo gênero, em diferentes períodos históricos. Conforme Ornebring (2003, p. 506), o gênero é uma teoria sobre produção e recepção dos produtos midiáticos e se constitui a partir de uma "complexa interelação entre intenção dos produtores e interpretação da audiência". O telejornalismo, enquanto gênero televisivo,abarca uma diversidade de subgêneros, como telejornais, programas de entrevista e documentários televisivos, e é justamente pelo conhecimento sobre as características de cada um dos subgêneros que o receptor sabe o que esperar dele Portanto, o gênero cumpre a função de posicionar a audiência em relação a um determinado produto.

O gênero também se constitui a partir de rupturas e transformações que, originadas na cultura, transportam para o gênero e seus subgêneros conceitos, comportamentos, crenças e discursos que o tensionam a seguir por outros caminhos e abordagens, mantendo marcas e elementos que se tornam dominantes (algo do presente que permanece no presente), residuais (algo do passado que permanece no presente) e emergentes (algo do presente que sinaliza um futuro). O residual refere-se a algo que foi formado no passado, mas que ainda assim está ativo no processo cultural. Por dominante, compreende-se aquilo que é efetivo, hegemônico. Por emergente, entende-seos novos significados e valores, as novas relações e tipos de relações que estão sendo continuamente criadas, como alternativas ou em oposição ao dominante (WILLIAMS, 1979, p. 124-129).

Nessa perspectiva, de acordo com Sacramento (2008, p. 195), os subgêneros são a manifestação concreta da "abstração" do gênero, enquanto os formatos são as opções estéticas para a realização de cada subgênero. O documentário televisivo pode ser descrito, então, como "um gênero com raízes históricas no cinema" que prezapela "seriedade" e pelo "aprofundamento do tema com entrevistas e produçãode imagens em diversos locais", buscando o máximo de informações possíveis (ARONCHI DE SOUZAapud SACRAMENTO, 2008, p. 195).

Em um de seus trabalhos mais recentes, Raymond Williams (2005) reforça que a televisão é uma tecnologia que é parte da cultura material cotidiana dos indivíduos e que as suas formas estabelecemuma complexa relação com outros 
tipos de cultura e de atividades sociais. Porém, esta relação não faz com que as formas televisivas sejam similaresàs que já existiam. Um jornal, por exemplo, não é igual a um telejornal, da mesma forma que um não deriva do outro. Sendo assim, um documentário televisivo não é uma cópia ou reprodução de linguagens técnicas e estéticas do documentário cinematográfico. Os dois produtos estão muito relacionados, mas são produzidos em (e para) diferentes mídias, quetêm histórias e usos distintos.

Para Williams (2005, p. 39-76), as formas da televisão (como as dequalquer meio de comunicação) são sempre socialmente construídas. Elas devem serencaradas como uma "produção cultural material", com objetivos e interessesespecíficos e fazendo parte de relações também específicas, visto que taisformas constituem um momento histórico e são constituídas por ele. Williams,então, rejeita as teorias que se atém à dimensão tecnológica - e estética -da televisão por meio de análises imanentes, que, "em si”, demonstram oimpacto e o valor damídia e de seus programas. Para ele, ao contrário, épreciso lidar com os "usos sociais da televisão" e as restrições socioculturais ehistóricas envolvidas no processo.

Dessa forma, todas as práticas sociais e seus significados têm uma dimensão cultural.É nesse sentido que Douglas Kellner (2001) afirma que os textos da cultura da mídia (ou os produtos culturais, nos termos de Williams) devem ser entendidoscomo um "terreno de disputa" que reproduz, em nível cultural, os conflitosfundamentais da sociedade, porque dela faz parte. Assim, a propósito de seu trabalho de análise de produções cinematográficas, Kellner afirma:

Um modo de delinear as ideologias da cultura da mídia é ver suaprodução em relação, situando os filmes, por exemplo, dentro de seugênero, de seu ciclo e de seu contexto histórico, sóciopolítico eeconômico. Ver filmes em contextosignifica ver como eles se relacionamcom outros filmes do conjunto e como os gêneros transcodificamposições ideológicas (KELLNER, 2001, p. 135-136).

Seguindo proposta de Williams (1979, 1992, 2005), acerca do que o autor denominou como "materialismo cultural", uma análise que tenha como viés a cultura deve estudar o sistema que constrange o que pode enão pode ser produzido, que impõe limites e possibilidades para a produçãocultural e que permite a análise dos efeitos materiais da cultura da mídia, como partes dos textos culturais e não como um elemento externo e apartado do produto. 


\section{DOCUMENTÁRIOS TELEVISIVOS BRASILEIROS}

O Globo Repórter, segundo programa jornalístico mais antigo da TV Globo, estreou em abril de 1973, com apresentação de Sérgio Chapelin, inaugurando na TV brasileira o formato de documentário televisivo. Conforme informações constantes no site Memória Globo², o jornalismo da Rede Globo, à época, começava a se solidificar, porém ainda não havia estrutura para a produção de um programa constituído basicamente de externas, o que levou a direção a reeditar a experiência do Globo Shell Especial, investindo na produção de cinedocumentários com narrativas conduzidas a partir das imagens, dos depoimentos dos entrevistados e da locução em offdo apresentador. Neste modelo, os repórteres não apareciam e diretores de cinema eram convidados a roteirizar os documentários.

De acordo com Costa (2009, p. 16-18), nos anos 70, o Globo Repórter apresentou um forte diálogo com o campo cinematográfico, o que foi possível graças ao momento de formação da linguagem televisiva, que, na década de 1960, aliava técnicas herdadas do cinema e do rádio ao fazer jornalístico.Os anos 80 foram marcadospela presença do repórter na condução da informação e a linguagem começa a se distanciar da cinematográfica e a se aproximar mais de um formato de reportagem televisiva. Características que, em linhas gerais, seguem definindo o gênero.

O SBT Repórter se apresenta, de acordo com texto da sua página eletrôni$\mathrm{ca}^{3}$, como um programa jornalístico que discute os assuntos por meio de investigação detalhada e tem como objetivo "mostrar fatos históricos, descobertas científicas e assuntos de curiosidade pública em geral”. Estreia em 1995 e surge com uma proposta muito parecida com a fórmula bastante testada do Globo Repórter.

O Câmera Record, programa mais novo do subgênero documentário televisivo da televisão aberta brasileira,estreou em 2008 e se afirma como um "programa jornalístico temático que traz grandes documentários produzidos pelas equipes de reportagem no Brasil e com a participação dos correspondentes internacionais", tendo como enfoque temático "assuntos de interesse da

2http://www.memoriaglobo.globo.com

3 http://www.sbt.com.br/sbtreporter 
população em geral, curiosidades, viagens, serviço, finanças e locais"4.

Seguido a este sucinto relato histórico e contextual acerca dos programas estudados, pode-se identificar, a partir da análise realizada, que muitos elementos herdados tanto do cinema, como a forma de enquadramento ${ }^{5}$, duração de cena, uso da fotografia, trilha sonora, modo de abordagem dos temas e dinâmica de produção, quanto do telejornalismo, como as entrevistas, o uso de offe apresentação em estúdio, são residuais na constituição do subgênero documentário televisivo, permanecendo como característicasregulares deste subgênero desde o fim da década de 1970.

Nos anos 2000, porém, embora presentes, os movimentos de câmera mais elaborados começam a ceder lugar a movimentos de plano sequência ${ }^{6}$, seguindo uma tendência emergente da grande reportagem de vivência, em que o repórter acompanha, por exemplo, o dia a dia da personagem que ilustra a situação tema do programa. Tal mudança aproxima-se mais, nesse caso, ao telejornalismo diário, com produções mais ágeis em função do pouco tempo para a elaboração e veiculação do material.

Outro elemento que, herdado do cinema, estabeleceu-se como constitutivo do subgênero é o uso de uma narrativa mais poética, com sequências em que tanto o uso do off quanto da fala do apresentador ou repórter busca, além de transmitir a informação, emocionar o telespectador. Esse tipo de narrativa também se apresenta, por vezes, mais próximo ao da linguagem telejornalística, ao estabelecer, por exemplo, no início de cada programa, uma escalada dos assuntos que serão tratados, momento em que o apresentador interpela o público com questões que serão respondidas ao longo da exibição.

Na década de 1980, outra transformação no modo de produção dos documentários televisivos é a adoção da dramatização para narrar a história, com o objetivo de ilustrar a reportagem ou para simbolizar algo da temática que está sendo debatida a fim de cobrir o offcom imagens, servindo também como uma

\footnotetext{
4 http://programas.rederecord.com.br/programas/camerarecord

50 enquadramento refere-se à composição da cena, ou seja, à preocupação com o posicionamento dos objetos e pessoas no cenário, atentando-se para a iluminação, hierarquia dos elementos, pontos de vista, reforçando, assim, sentimentos, emoções e as intenções da cena.

60 plano sequência é uma forma de captação de imagens sem cortes ou novos enquadramentos de câmera, em que o repórter cinematográfico acompanha de perto a ação, sem desligar o equipamento, registrando tudo que está acontecendo.
} 
passagem de escalada, como foi identificado no programa sobre Depressão, do SBT Repórter, exibido em 25 de abril de $2011^{7}$.O recurso da dramatização é hoje um elemento residual, emergindo na década de 1970, conforme crítica publicada na edição 341 de Veja:

Em busca da reconstituição histórica das últimas 24 horas do legendário cangaceiro Lampião, a equipe dirigida pelo cineasta Maurice Capovilla, 39 anos, optou por uma forma pioneira dentro do telejornalismo brasileiro, ao reunir testemunhos de personagens reais, contemporâneos do bandoleiro, ao trabalho de atores, que reconstituem os fatos ${ }^{8}$.

Outra marca característica dos documentários televisivos da TV aberta brasileira, com forte influência do telejornalismo, é a presença do apresentador em estúdio, que tem por função reger o programa, apresentando o tema, interpelando a audiência, anunciando as entrevistas e as personagens. Nos anos 70 e 80, o âncora ocupava uma bancada assim como nos telejornais e, dali, tornava-se a imagem central do programa, como Sérgio Chapelin, apresentador do Globo Repórter desde suas primeiras exibições, e Marília Gabriela, no comando do SBT Repórter desde o começo do programa, alternando períodos em que esteve à frente de outros projetos da emissora.

Em uma das edições do SBT Repórter, de 1997, sobre o filme Titanic, Marília Gabriela está posicionada em uma bancada, interpelando diretamente o telespectador, e, utilizando uma linguagem poética, descreve o Titanic como um navio "naufragado na vida real e imortalizado no coração de todos nós". Ao longo do programa são exibidas imagens do filme e dos bastidores, entrevistas com produtores e equipe do filme, sobreviventes e especialistas. O texto, em off, é bastante marcado, também, pela adjetivação, como nos termos: "esforço monumental”, "mar de dinheiro", "prodígio cinematográfico".

A partir desse exemplo, é possível aferir que o SBT Repórter, assim como os outros que se inserem no subgênero em análise, posiciona-se discursivamente como o aliado do público, como o programa que busca as respostas para as questões do cotidiano que preocupam ou chamam a atenção do telespectador. Esse posicionamento está diretamente relacionado ao modo como o âncora conduz o programa, à forma como expõe os questionamentos, se

7 Disponível em http://www.youtube.com/watch?v=AaJHN_8KM3s

8 MORAES, Renato. Boa Abertura. Revista Veja. Edição 341, 19 de março de 1975. 
movimenta no cenário e olha para a câmera.

Sobre o cenário, identifica-se uma mudança mais incisiva na década de 2000,quando o espaço passa a ser virtual, perdendo a bancada. Neste novo cenário, o apresentador está em pé e passeia livremente, conversando com as várias câmeras espalhadas pelo estúdio. O modo de narrar o tema do programa assemelha-se a um diálogo com o telespectador, por meio do olho no olho e da interpelação constante, como no enunciado a seguir: "e qual o segredo para conquistar uma nação?" . O tema e seus desdobramentos são apresentados em uma escalada rápida com informações e imagens.

O âncoraemerge, então, como o regente do programa, como a figura que o caracteriza, vide a escolha da Rede Globo em manter o jornalista Sérgio Chapelin à frente do Globo Repórter, desde o início das exibições. Tal estratégia mantém-se seguindo uma fórmula que tem agradado o público: "No Globo Repórter, certamente o que mais brilha é o âncora Sérgio Chapelin. Sua voz suave e temperada cruza décadas, imprimindo o mais apropriado tom aos melhores jornalísticos e documentários da TV brasileira", conforme manifestação de um dos leitores da Revista Veja ${ }^{10}$.

Além do apresentador, outro profissional que passa a ocupar mais espaço dentro dos programas a partir da década de 1980 é o repórter. Com um viés mais investigativo, o Globo Repórterdeste período já mostrava indicativos dessa marca que viria a ser emergente no subgênero documentário televisivo, na medida em que o repórter deixa os bastidores da notícia (apuração, gravação de entrevistas, redação e locução de textosem off)e aparece cada vez mais na tela, com maior autoridade discursiva para condução da reportagem.

Um exemplo dessa maior importância discursiva conquistada pelo repórter, é a edição do dia 29 de agosto de 1995 do SBT Repórter, em que foi divulgada, com exclusividade, segundo o programa, uma entrevista com o ex-presidente Fernando Collor de Melo"1. Na ocasião, o repórter Roberto Cabrini permanece durante todo o programa ao lado da apresentadora Mônica Waldvogel, na bancada do estúdio, comentando sobre os bastidores e as repercussões da reportagem, bem como tecendo opiniões acerca da vida que Collor estava levando em seu exílio voluntário nos Estados Unidos.Sobre esta edição do SBT Repór-

9 César Filho, SBT Repórter, Programa de 17 de agosto de 2011.

10 Álvaro Tojal. Sessão Cartas. Revista Veja, 11 de agosto de 2005.

11 Disponível em http://www.youtube.com/watch?v=QDQW5EkyjHI 
ter, a Revista Veja afirmou que o "programa prende a atenção do começo ao fim" e que se trata da "melhor reportagem de jornalismo exibida na televisão neste ano"12.

A edição do SBT Repórter que veiculou a entrevista com Collor marcou a estreia do jornalista Roberto Cabrini na emissora e deu o tom para as futuras reportagensproduzidas pelo programa: perguntas contextualizadas, diretas e desconcertantes, que evidenciam as fragilidades e seguranças do entrevistado. Tais características tornaram-se marcas regulares do programa, que pode ser considerado mais como integrante do gênero telejornalismo, veiculando grandes reportagens, ou até mesmo, conforme críticas da imprensa, aproximando-se do infotainment ${ }^{13}$ :

Para conseguir médias de audiência na casa dos 17 pontos, boas para o horário noturno em que é veiculado, o SBT Repórter investe no chamado jornalismo-show. Nessa linha, já produziu espetáculos desagradabilíssimos, como aquele que focalizou uma colônia de nudismo nos Estados Unidos. Quem viu jamais esquecerá as celulites exibidas em close e a extraordinária performance do repórter, que resolveu tirar a roupar para esquentar o programa ${ }^{14}$.

Seguindo essa marca residual do repórter cadavez mais presente no programa, o modelo de reportagem de vivência, na qual o profissional acompanha a rotina da personagem que humaniza o relato, apresenta-se com um elemento emergente no modo de fazer do documentário televisivo.Desde os anos 2000, conforme foi possível identificar na análise dos programas, o repórter vivencia a reportagem, realiza a entrevista de modo mais participativo, entra no plano, no enquadramento, permite se emocionar com a fala da personagem. Nesse formato, o repórter é quem conduz a reportagem, adentrando o espaço, conhecendo e apresentando as personagens ao público. O texto em off é menos utilizado, o que remete a uma narrativa mais livre, menos trabalhada em termos estéticos, quase tendendo ao improviso.

12 Elle voltou. Revista Veja - sessão Imprensa. Edição 1408. 06 de setembro de 1995.

13 Trata-se de termo utilizado para designar os programas, principalmente do gênero telejornalismo, que unem informação e entretenimento (GOMES, 2012).

14 Primeira-dama. Veja - sessão Televisão. Edição 1598. 19 de maio de 1999. 
Em se tratando dos temas dos programas ${ }^{15}$, foi possível identificarque, dos anos 70 até hoje, os assuntos variaram de um enfoque mais político e de resgate histórico, como as narrativas sobre os garimpeiros de Serra Pelada e o Cangaço, para grandes relatos de viagem e programas com foco na saúde, educação ou cotidiano, passando, nas décadas de 1980 e 1990, por grandes reportagens investigativas, em que os repórteres colecionaram méritos por terem identificado corpos de presos políticos mortos durante a ditadura ou por encontrarem criminosos condenados e escondidos em outros países.

Tal perfil temático pode ser considerado uma regularidade dos programas brasileiros filiados ao subgênero documentário televisivo. Mesmo o SBT Repórter, que é da década de 1990, e o Câmera Record, de 2008, já incorporaram características que se tornaram dominantes em termos de enfoque temático. Ou seja, dos anos 90 até hoje, os programas têm buscado cada vez mais levar ao público assuntos cotidianos, que interferem diretamente no dia a dia das pessoas. Temas como saúde, educação e viagens ganham destaque em uma sociedade que tem melhorado o nível de renda e a expectativa de vida, estando cada vez mais preocupada em viver bem, com qualidade, saúde e diversão, principalmente viajando e aproveitando as novas tecnologias.

Embora pareçam aleatórios, os temas seguem rodízios e categorizações previamente definidas pelas produções dos programas. O Globo Repórter, por exemplo, organiza os assuntos em quatro selos temáticos: comportamento, aventura, ciência e atualidades. A categoria comportamento abarca temas sobre modos e histórias de vida. No selo aventura, estão reportagens sobre natureza, turismo, regiões inóspitas, vida no estrangeiro. O selo ciências reúne as produções que tratam de saúde, descobertas, inovações, tecnologias. $\mathrm{E}$ na categoria atualidades estão matérias sobre serviços e orientações em geral (COSTA, 2011, p. 158).

Mas a história do Globo Repórter coleciona algumas críticas com relação aos temas escolhidos e a forma de abordagem. Na edição 404 da Revista Veja, de 1976, por exemplo, Guilherme Cunha Pinto satiriza a discussão levantada pelo programa sobre a existência de extraterrestres no Brasil, chamando de "furo universal da Rede Globo: disco voador existe". Segundo o crítico:

15 Os temas dos programas estão disponíveis em seus endereços eletrônicos e, no caso da Rede Globo, também no site do Memória Globo. 
em suma, essa edição do 'Globo Repórter - Aventura' inclinou-se decididamente mais pela aventura que pela reportagem. Mesmo porque não cultivou a preocupação da pergunta. (...) Assim, ao tratar um assunto no mínimo discutível com uma superficialidade já perigosamente característica, o 'Globo Repórter - Aventura' corre o risco de conseguir indesejáveis efeitos paralelos. Por exemplo: mais fácil acreditar em disco voador do que no programa ${ }^{16}$.

O mesmo Guilherme Cunha Pinto reconheceria, no ano seguinte, o esforço do programa ao produzir um documentário que contava a história de vida de ex-alunos de uma classe primária de 1955, evidenciando o que havia acontecido na vida dessas pessoas depois que deixaram a escola. De acordo com o crítico, a edição do Globo Repórter havia sido: "simplesmente e disparado o melhor programa que passou pela TV brasileira este ano. Por tudo, pelos caminhos que abre, pela originalidade da ideia e de execução, conteúdo dramático dentro de um jornalismo do mais alto nível"'

Assuntos do cotidiano, como economia, saúde, aventura, lugares e animais exóticos revelaram-se mais presentesno Câmera Record. Há duas possíveis explicações para essa afirmativa: uma é que, por ser mais novo, o programa adotou estratégias reconhecidamente exitosas testadas pelos concorrentes, focando-se mais nos assuntos que costumam agradar e gerar mais audiência. Outra explicação é que a emissora (Record) possui em sua grade outro programa também de documentários e grandes reportagens, mas com viés investigativo e policial, o Repórter Record., agregando nele os assuntos que podem ser tidos como mais "pesados".

A análise identificou, ainda, que os programas do subgênero documentário televisivo veiculados na TV aberta brasileira são marcados pela estratégia de transmitir a informação da maneira mais didática possível, oferecendo orientações, receitas e soluções fáceis aos telespectadores, utilizando recursos técnicos como animações e computação gráfica e abordagem que evoca a desmistificação de temas, seguindo o clássico formato mitos $x$ verdades.

Esse formato pedagógico adotado pelos programas pode ser considerado

16 PINTO, Guilherme. Furo mundial. Revista Veja - sessão Rádio e TV. Edição 404, de 02 de junho de 1976.

17 PINTO, Guilherme. Primoroso. Revista Veja - sessão Televisão. Edição 485, de 21 de dezembro de 1977. 
hoje um elemento dominante no subgênero, com origens na década de 1980 quando, nacionalmente, a a democratização do País confere à população uma importância aos olhos dos produtores de conteúdo televisivo. Além disso, nessa época, o acesso à televisão começa a aumentar, levando as emissoras a definirem estratégias de sedução e fidelização desse novo público consumidor e uma delas é justamente aliar temáticas e abordagens que mais se aproximam do cotidiano das pessoas.Assim, o Globo Repórter, único programa do subgênero documentário televisivo em exibição à época, buscou unir informação e entretenimento de modo a atrair ainda mais a atenção do telespectador. $\mathrm{Na}$ sua fase mais contemporânea, o Globo Repórter, seguido pelos seus concorrentes, é marcado por estratégias de aconselhamento e de diversão, predominando recursos de espetacularização da informação, um exemplo clássico doinfotainment.

O fato é que, em qualquer período nestes quase 50 anos de programas de documentários televisivos na televisão brasileira, as emissoras e produtores precisaram adaptar-se a mudanças, rupturas e transformações no modo de consumir e ver televisão no Brasil e no Mundo. No site do Memória Globo, a própria emissora reconhece, em pelo menos dois momentos, que fez mudanças no formato e na linguagem do programa para atender melhor às expectativas da audiência, visando a "unir mais eficientemente notícia e entretenimento" e para "interessar ao telespectador de todas as classes".

Tais mudanças e rupturas no modo de produção dos programas são tensionamentos e anseios da sociedade, ou seja, oriundas de transformações na cultura. Asessão Televisão, da Revista Veja de agosto de 2005, afirma que o Globo Repórter mudou com os novos tempos do documentário, mas que nem sempre acerta o tom. O texto reconhece que o programa "desbravou a seara dos documentários na televisão brasileira" e que vem se adaptando ao novo cenário do avanço das TVs pagas ao abrir espaço para a retransmissão de grandes produções estrangeiras. Porém, quando se trata de reportagens sobre natureza ou antropologia cultural, avalia a crítica, o programa mantém o "mesmíssimo espírito dos anos 70"18.

Embora elencando aspectos negativos com relação às estratégias utilizadas pelo programa, Veja acredita que o Globo Repórter ainda conserva seu

18 O Discovery dos sem cabo. Revista Veja - sessão Televisão. Edição 1916, 3 de agosto de 2005 . 
"apelo" apesar do "formato à moda antiga" e que sua audiência garante-se, também, pelo fato de não ter concorrentes à altura.

\section{CONSIDERAÇÕES FINAIS}

A cultura está em constante transformação, constituindo-se de diálogos, tensionamentos e rupturas. $\mathrm{E}$ os produtos culturais, como os gêneros televisivos, acompanham esse movimento, adaptando-se constantemente às novas configurações e cenários. Nesse sentido, é possível afirmar que o subgênero documentário televisivo, nesses quase 50 anos em que vem se (re)configurando na TV aberta brasileira, mostrou-se, conforme a presente análise, como um subgênero híbrido, na medida em que está em processo constante de transformação agregando elementos residuais, dominantes e emergentes de gêneros cinematográficos e de gêneros televisivos: um misto entre documentário e telejornalismo.

E essa hibridização não está deslocada de contexto, uma vez que a globalização tem deixado as fronteiras abertas e maleáveis, possibilitando a apropriação, pelos produtos culturais, de elementos das mais variadas culturas e tempos históricos e fazendo com que os gêneros narrativoscada vez mais deixem de ser fixos, para serem mutáveis, em grande velocidade, em vista também da maior possibilidade de intervenção e participação do público.

Trata-se, portanto, de um subgênero televisivo que, aliando técnicas e linguagens do cinema documentário e da grande reportagem, tem como elementos dominantes o perfil temático das pautas, voltado para narrativas sobre modos de vida e cotidiano, as formas de abordagem, mais didática e orientativa, as formas de apresentação do assunto, utilizando recursos gráficos, comparativos e muitos exemplos.

Entre os elementos emergentes identificados na análise é possível destacar uma grande tendência à maior utilização de recursos de interatividade, principalmente pela Internet, e maior participação da audiência, aspecto que os teóricos dos Estudos Culturais já chamavam a atenção há algumas décadas: os consumidores dos bens culturais estão cada vez mais envolvidos e participantes, tanto na definição do conteúdo como com sua própria produção.

Embora alguns autores como José Carlos Aronchi de Souza (ARONCHI, 2004, p. 145-146 apud SACRAMENTO, 2008, p. 195) acreditem que, no passado, Globo Repórter e SBT Repórtereram os programas que mais se filiavam ao sub- 
gênero, mas, que, por razões mercadológicas, passaram a reduzir seus tempos de duração, o que desvirtuou "o caráter de documentário" das produções, que passaram a merecer "apenas o crédito de grande reportagem", é possível inferir, pela análise, que características do documentário, como a forma de enquadramento, duração de cena, uso da fotografia, trilha sonora, modo de abordagem dos temas e dinâmica de produção, são elementos residuais dentro da constituição do subgênero do documentário televisivo, mesmo que a duração dos programas tenha diminuído, ou seja, somente o fator tempo não deve ser considerado determinante para se estabelecer se um programa é ou não um documentário televisivo, uma vez que ele não é uma cópia ou reprodução de linguagens técnicas e estéticas do documentário cinematográfico, mas um híbrido entre cinema e telejornalismo. Esses dois produtos estão muito relacionados, mas são produzidos em (e para) diferentes mídias que têm histórias e usos distintos e que, ao se agregarem, formam um novo produto.

A análise possibilitou vislumbrar, ainda, uma hipótese que precisa ser aprofundada em estudos futuros: a de que não há, no atual cenário da TV aberta brasileira, uma linguagem ou um formato fixo do subgênero documentário televisivo. Este trabalho identificou que, de acordo com a temática tratada, com o modo de produção e as estratégias discursivas adotadas, o produto final tenderá a se aproximar mais de um documentário ou mais de uma grande reportagem.

Por fim, ao se analisar os comentários e críticas da imprensa, é possível concluir que o subgênero documentário televisivo ainda carece de consensos acerca de sua linguagem ou formato, já que os programas reconhecidos como integrantes deste subgênero, e aqui analisados, são em alguns textos chamados de documentários e em outros como reportagens. Isso pode conduzir a uma comprovação de que o hibridismo é uma característica dominante do subgênero que está em constante reconfiguração pelas emissoras, na busca por atender as expectativas de informação e entretenimento dos seus telespectadores.

\section{REFERÊNCIAS}

COSTA, Marília Hughes Guerreiro. O modo de endereçamento do Globo Repórter: uma análise a partir de três períodos historicamente distintos. Dissertação de Mestrado do Programa de Pós-Graduação em Comunicação e Cultura Contemporâneas: PósCom/UFBA, 2009. 
(org.). Gênero televisivo e modo de endereçamento no telejornalismo. Salvador: EDUFBA, 2011, p. 151-171.

GOMES, Itania Maria Mota (org.). Gênero televisivo e modo de endereçamento no telejornalismo. Salvador: EDUFBA, 2011.

- Tendências do telejornalismo brasileiro no início do século XXI: telejornalismo popular e infotainment. In: FREIRE FILHO, João; BORGES, Gabriela (orgs). Estudos de televisão: Diálogos Brasil-Portugal.Porto Alegre: Sulina, 2012.

MEMÓRIA GLOBO. Globo Repórter. [2008]. Disponível em: <http://memoriaglobo.globo. com/Memoriaglobo/0,27723,GYNo-5273-238604,00.html>. Acesso em: 15/08/2012.

ORTIZ, Renato. A moderna tradição brasileira: cultura brasileira e indústria cultural. $5^{\text {a }}$ edição.Brasiliense: São Paulo, 1994.

ÖRNEBRING, Henrik. Televising the Public Sphere: Forty years of current affairs debate programmes on Swedish.Television European Journal of Communication. Vol 18(4), 2003: 501-527.

SACRAMENTO, Igor. O documentário televisivo como texto cultural: narrando uma opção metodológica. Revista do NP em Comunicação Audiovisual da Intercom, São Paulo, v.1, n.1, p.193-210 jan./jun. 2008.

WILLIAMS, Raymond. Cultura. Rio de Janeiro: Paz e Terra, 1992.

. Marxismo e literatura. Rio de Janeiro: Jorge Zahar, [1971] 1979.

. O campo e a cidade. São Paulo: Companhia das Letras, [1973] 2011.

. Cultura e materialismo. São Paulo: Editora Unesp, 2011.

. Television: technology and cultural form. London: Routledge, 2005.

\section{Sites}

CÂMERA RECORD.Disponível em: http://programas.rederecord.com.br/programas/camerarecord. Acesso em: 18 setembro 2012.

MEMÓRIA GLOBO. Disponível em: http://www.memoriaglobo.globo.com. Acesso em: 15 setembro 2012.

SBT REPÓRTER. Disponível em: http://www.sbt.com.br/sbtreporter. Acesso em: 15 setembro 2012.

MORAES, Renato. Boa Abertura. Revista Veja. Edição 341, 19 de março de 1975. Disponível em http://veja.abril.com.br/acervodigital. Acesso em: 20 setembro 2012.

PINTO, Guilherme. Furo mundial. Revista Veja - sessão Rádio e TV. Edição 404, de 02 de junho de 1976. Disponível em: http://veja.abril.com.br/acervodigital. Acesso em: 20 setembro 2012.

PINTO, Guilherme. Primoroso. Revista Veja - sessão Televisão. Edição 485, de 21 de dezem- 
bro de 1977. Disponível em: http://veja.abril.com.br/acervodigital. Acesso em: 20 setembro 2012.

REVISTA VEJA. Elle voltou. Edição 1408.6 de setembro de 1995. Disponível em: http://veja. abril.com.br/acervodigital. Acesso em: 20 setembro 2012.

REVISTA VEJA. Hipocondria. Edição 605, de 9 de abril de 1980. Disponível em: http://veja. abril.com.br/acervodigital. Acesso em: 20 setembro 2012.

REVISTA VEJA. O Discovery dos sem cabo. Edição 1916, 3 de agosto de 2005. Disponível em: http://veja.abril.com.br/acervodigital. Acesso em: 22 setembro 2012.

REVISTA VEJA. Primeira-dama. Edição 1598. 19 de maio de 1999. Disponível em: http://veja. abril.com.br/acervodigital. Acesso em: 21 setembro 2012.

TOJAL, Álvaro. Sessão Cartas. Revista Veja, 11 de agosto de 2005. Disponível em: http://veja. abril.com.br/acervodigital. Acesso em: 20 setembro 2012.

RECEBIDO EM: 30/10/12

ACEITO PARA PUBLICAÇÃO: 18/12/12

\section{Ivanise Hilbig de Andrade}

Jornalista, Mestre em Estudos de Linguagens (UFMS) e Doutoranda em Comunicação e Cultura Contemporâneas (UFBA). Integrante do Cepad (Centro de Estudos e Pesquisas em Análise do Discurso) e consultora do CCDC (Centro de Comunicação, Democracia e Cidadania) Facom/UFBA. 